\title{
DEVELOPMENT OF AGRO-TOURISM IN GURIA REGION AND POTENTIAL FOR ITS USE
}

\section{SALOME SULABERIDZE}

PhD, Student,

Batumi Shota Rustaveli State University, Georgia

salome.sulaberidze@list.ru

\section{MURMAN TSETSKHLADZE}

Doctor of Economics,

Associate Professor,

Batumi Shota Rustaveli State University, Georgia

murman.tsetskhladze@bsu.edu.ge

Abstract. The paper analyzes the possibilities of making full use of the agro-tourism potential in the Guria region on the basis of agricultural development, engaging tourists in agricultural activities and promoting various spectacular events, promoting the colorful or cultural individuality of the region. Recommendations for overcoming the problems in the development of agro-tourism in the region are proposed.

\section{KEYWORDS: FARM, AGRO-TOURISM, WINEMAKING, BEEKEEPING, AGRICULTURAL PRODUCT.}

For citation: Sulaberidze, S., Tsetskhladze, M., (2021). Development of Agro-Tourism in Guria Region and Potential for its Use. Globalization and Business, №11, 133-138. https://doi.org/10.35945/gb.2021.11.019

\section{INTRODUCTION}

Issues of agro-tourism development in Georgia have been more or less studied by Georgian and foreign scientists. Among Georgian authors it is worth to mention papers of $\mathrm{E}$. Kharaishvili, M. Metreveli, G. Bedianashvili, N. Jabnidze etc. The studies conducted by the Georgian Ecotourism Association and travel agencies located in the regions are also important. However, there is still a lot to learn about it.

Georgia and one of its regions - Guria - has many opportunities for the development of agro-tourism, which should be considered in connection with the development of agriculture. The soil-climatic conditions of the region allow the development of such fields of vegetation as citrus, tea cultivation, berry crops, subtropical fruit production, etc. As well as prospects for the development of flower and greenhouse farms. Livestock, poultry and pond farms are widespread in all three municipalities of the region.

The main principle of agro-tourism development in Guria is: tourists resting in a clean environment, engage in their rural activities, get acquainted with Gurian hospitality, which gives great pleasure to tourists, and brings additional income for farmers. However, many problems can be overcome for the development of agro-tourism as well. Among them are the scarcity of financial resources and infrastructure malfunctions, which cannot be addressed by local efforts. Consequently, the development of agritourism requires the development of an adequate strategy, which should ensure its prosperity and effective management.

We believe that the success of one of the major factor is, that the activities in the implementation of a chain of each individual and the collective of JSC impact on the region as a tourism destination development, as well as local employment and economic well-being.

\section{AGRITOURISM RESOURCES AND POTENTIAL OF GURIA REGION}

Guria region has significant potential for agro-tourism, which can be activated and developed in connection with the development of certain agricultural sectors, which will develop infrastructure, improve rural living conditions, suppliers of agricultural products will have an additional source of income, will employ locals, will provide affordable food for vacationers. Caring for the natural environment will become more important.

With similar approaches, many countries around the world have been able to solve the socio-economic problems of rural areas. In many countries, various policies have been 
developed and successfully implemented by government agencies to promote the concept of agro-tourism development and maintenance.

For example, this issue is considered an important part of the tourism industry in Germany. The main requirement for a holiday in Germany today is to rest in the countryside, in a quiet environment and relax (Jabnidze).

In Guria region, there are currently many farms that offer visitors interested in agro-tourism to engage in agro-activities and taste the natural village corp rewards.

For example, visitors can visit the Ozurgeti, village Tsitelmta the agroturizm involved in the household, with a guesthouse "Komli", the tea plantations of its farm, and offers tourists a family guest-house to stay overnight, a tea garden in the tea collecting and his own hand-tea-making service. There is a vegetable garden where fresh and pickled vegetables are served directly at the tourists' table. It is especially attractive for tourists visiting the hotel with families and young children.

To stay here with various international travel platforms, tourists from all over the world book a place well in advance. Thailand, China, Russia, England, Germany, the Netherlands, the United States - this is a non-exhaustive list of countries from which "Komli" had guests and is still waiting after the defeat of the pandemics.

There are many elements characteristic of Gurian life and culture. Such as, for example, traditional Gurian Ketsi - a special, flat stone made of Ketsi stone, on which "Mchadi" (bread made of maize) and Gurian pie are made. Also, the kiln stone-chamuri, which was traditionally used for baking cereals, etc.

The family farm has cultivated about 60 unique endemic varieties of vines. He also planted several rare vine varieties for demonstration: Gurian Mtevandidi, Sakmeela, Kamuri, Rtskhilatubani and Badagi. Is going to contribute to the development of the ancient viticulture in Guria along with tea. During the cultivation of vines on the slope was found damaged, though the oldest and rarest cellar with pitchers, which are presumed to belong to the late medieval period. It is planned to arrange a modern cellar next to the mentioned cellar, where they will put Gurian wine from traditional Gurian vine varieties.

Original overnight facilities are arranged: Visitors can spend the night in specially arranged "Nalia" and "Kvevri" type restrooms (Kushashvili, 2019).

Also interesting is "Menabde's Cellar" - a typical Gurian yard in the village of Shemokmedi. Oda-type house, an ancient building that has been completely restored and is already receiving guests. The owners kept the traditional look as much as possible.

The main focus of the Menabde's Cellar is wine. More than 4000 Chkhaveri have been planted there. The goal is to increase wine production and develop the Georgian market.

"Menabde's cellar" has 5 double rooms. 4 rooms are located in the central building, one separately, in the building of so called Gurian "Kukhni ". Traditional Gurian cuisine is one of the sights of the place with a huge orchard.

They have about 20 varieties of apple trees, up to 10 pears, cherries, almonds, lemons. Tourists will even see a banana tree in the yard. Lots of dried fruits and jams are prepared to please and entertain the guests. They have traditional Gurian cuisine and culinary master classes (Gelovani, 2019).

In general, the "agro-tourism product" has its own specifics. Almost all the countries of the world has particular types of food and beverage production Promotion of Agritourism has a specific purpose, which in turn brings added value to a specific product. In many countries this is regulated by quality signs: signs of product origin, geographical location and tradition.

A good example of this is champagne and cognac in France, Gorgonzola cheese and Parimano-Regiano in Italy. This strategy is based on agritourism routes such as the Wine Route, the Artisan Cheese Route, the Beer Rout. "Cedra route" is popular in the Basque Country (Khartishvili, 2020: 17).

Guria, like other countries, produces various types of food and beverages for agro-tourism purposes. For example: here tourists can taste acacia, chestnut, lime, alpine meadow honey.

Honey is used not only for food, but also for making vodka. In general, vodka is spread all over Guria. Along with vodka distilled from chacha and fruit, candle vodka is also popular, which is called "Buzi Otka" in Guria. (Historical, 2019)

Nowadays, tourists are offered bee products by Gurian farmers involved in agroturism: Givi Ninidze (Ozurgeti 's municipality, village Vakijvari); la Urushadze, produces branded honey "Bee Nobati" (Ozurgeti municipality, village Vakijvari); Lali Chakseliani, produces branded honey "Mischer" (Ozurgeti municipality, village Baileti); Chabuka Patsuria Cooperative "Modern Beekeeping" (Lanchkhuti Municipality, village Gvimbalauri); Individual entrepreneur - Jaba Cheishvili, whose activity is multidisciplinary. Along with beekeeping, it pursues floriculture (Ozurgeti municipality, village of Makvaneti) and others.

We think it is better to offer tourists not only to bee products, but also to conduct a tour of the apiary with certain rules: excursion should be arranged and organized in order to prevent a chaotic visit.

Small bee lectures can also be arranged in the apiary. Visitors can be shown beehive and activities of the bee family, as well as see the honey in the usual beehives.

Also, it is necessary to pay attention to the safety of visitors. Should there be a quiet environment, it is essential for guests of all ages to have beekeeping overalls.

The main income from the excursion to the beehive should preferably be the proceeds from the products sold, for which the honey for sale and other bee products should be provided to the buyer in an attractive way, namely:

Honey, preferably poured into small beautifully decorated containers;

Beeswax honey placed in decorative frames can be easily sold, as well as decorative candles made of wax, propolice, flower dust etc should be supplied in attractive packaging ( Ghoghoberidze, 2017: 118-120).

It is also necessary for the agro-tourism product to be targeted at a certain segment. In this regard, agro-tourists can be divided into the following groups:

- Parents with young children - this segment includes 
children aged 12-14 and those parents for whom children's fun and cognition is the defining factor of travel;

- Older tourists - this segment includes pensioners over the age of 60 , mostly retirees;

- Nature lovers - this is the largest segment, which includes travelers individually, in groups or in pairs. Sometimes friendly families travel together. The group focuses on environmental protection, organic farming, responsible tourism product, interest in agriculture and ecology, physically active; (Khartishvili, 2020: 48-51).

As it can be seen from the diagrams (see Charts 1, 2, 3), the share of agro-tourists in the total flow of tourists in the Guria region is still small, as is the share of foreign tourists.

The trend of increasing the number of visitors is also noteworthy. We think this trend will continue even after the defeat of the pandemic.

For example, as the diagrams show, the total number of visitors to Ozurgeti Municipality in 2018 was 7,500, of which 1,500 were foreign visitors and 225 were interested in agritourism. In 2019 the total number of visitor was 9,800, from which 2,100 were foreigners and 294 interested in agritourism (Shalamberidze, 2019).

The number of visitors to Chokhatauri Municipality in 2015 was 12,000, in 2016 - 18,000, in 2017 - 1,860, in 2018 - 18,800, in 2019 - 19,000. Of these, the number of tourists interested in agritourism in 2019 is 3\% of the total that is 564 visitors (Sharashenidze, 2019).
The number of visitors is also increasing in Lanchkhuti municipality: from 2016 to 2019 the number of two years' tourists was 4,939.

Also noteworthy is the fact that the region is characterized by the seasonal tourist flows (see. Figure 4), for example, in Lanchkhuti, in 2019, the number of visitors has increased dramatically in July and August, while the smallest was in June and October. The other 200 tourists came in during the other remaining months of the year (Gujabidze, 2020).

We think that after the defeat of the pandemic, tourism will again occupy one of the leading places in the economy of our country, in which the Guria region will also contribute.

\section{MEASURES TAKEN AND PLANNED FOR THE DEVELOPMENT OF AGRO-TOURISM IN THE GURIA REGION}

Since 2019 the Agrarian Issues Committee on agriculture bill, whose main objective in Georgia living in rural areas increased their economic engagement to raise, promotion of employment and income for the local population growth. The effective date of the law is June 1, 2021 (Nikvashvili, 2020).

Within the project, "Participatory Principles for Guria Tourism Development Strategy", a strategic plan for tourism development in the Guria region was created. The plan outlines the development priorities of the region, where signifi-

Diagram N 1. Number of tourists in Ozurgeti municipality (2018-2019)

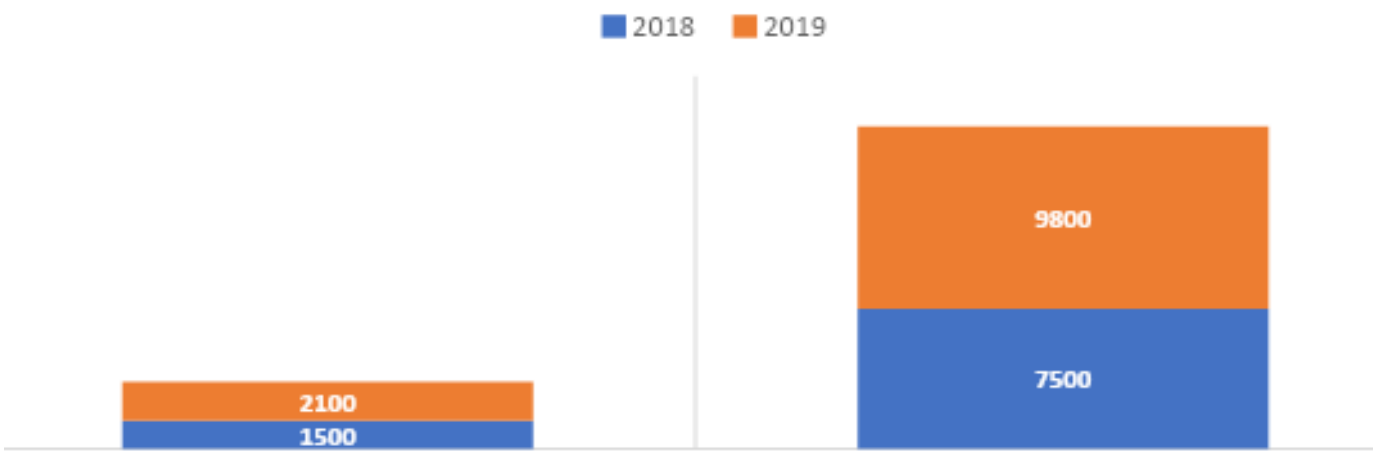

Source: Ozurgeti Municipality City Hall, Tourism Service.

Diagram N 2. Number of visitors in Chokhatauri district in 2015-2019.

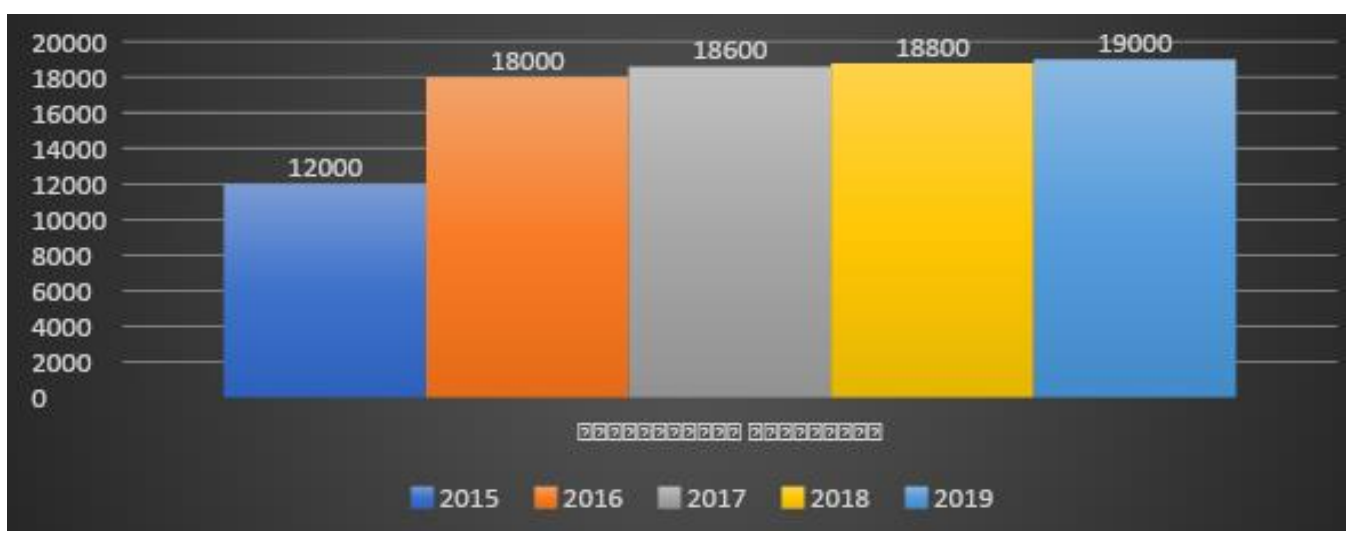

Source: Chokhatauri Municipality City Hall, Culture Service. 
Diagram N 3. Number of visitors in Lanchkhuti municipality in 2016-2019.

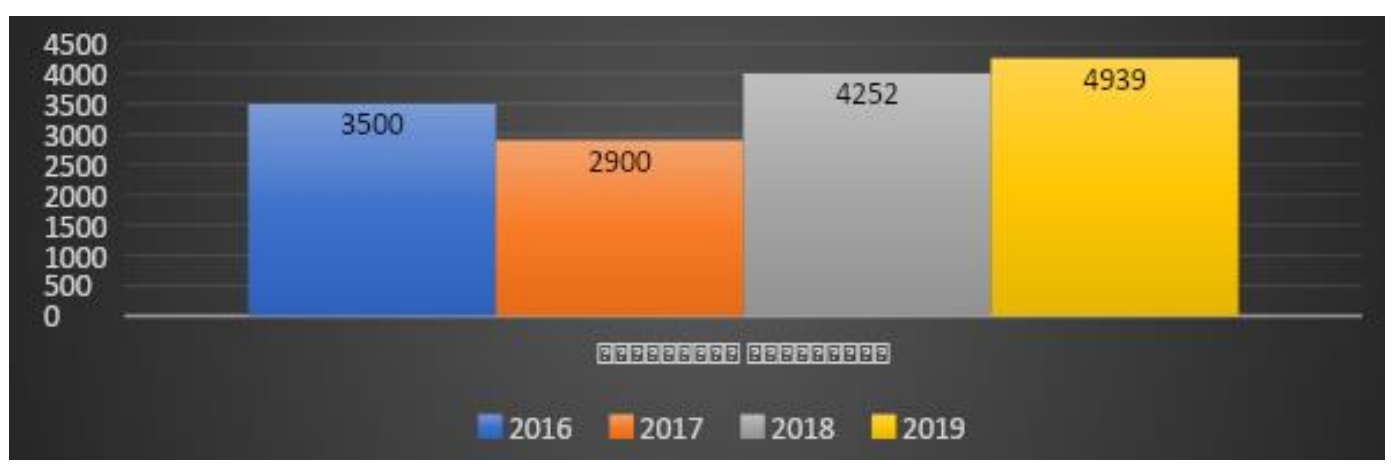

Source: Lanchkhuti Municipality City Hall, Tourism Service.

cant place and have even destroyed agritourism. Municipalities have developed action plans for tourism development.

Similarly, an agritourism action plan is being developed and implemented in European countries, where agritourism is regulated by a number of legislative and normative acts, including the Municipal Zoning Plan (local self-government), the Housing Law, the Regulation on Building Regulation (environmental safety) and, Law on Environmental Management and others (Gugushvili, 2013: 26).

In Italy, for example, the National Law on Agritourism, which came into force in 1985, regulates additional business activities on farms to diversify farmers' incomes, farming practices, agricultural buildings and the preservation of traditional landscapes (Khartishvili, 2020: 12).

Within the framework of the project, "Participatory Principles for Guria Tourism Development Strategy", the "Guria Agro-Tourism Festival " is being held in stages, with the aim of promoting agricultural products produced in Guria municipalities, raising awareness of local rural products and tourism service providers. In rendering.

For example, within the framework of the agro-tourism festival, an exhibition-fair markets of products produced by the local population was held, in which more than 50 farmers, entrepreneurs or representatives of cooperatives from the Guria region took part (Girkelidze, 2018).

This festival allows us to present Guria as an attractive place for visitors interested in agritourism, to promote the natural resources and development opportunities available here.
For example, olives from Guria were abundant abroad until 1927. That is, there were olive groves here. Today, $100 \%$ of olives are imported from abroad.

Just as blueberries were grown and are now being exported abroad in tons, it is also possible to grow olives. Over time, it also can become a blueberry brand for Guria.

Guria also has all the conditions for creating Georgian brands of fisheries or beekeeping (Eradze, 2017).

The availability of advertising means, including agro-tourist maps, is also important for visitors to get acquainted with Guria. For this purpose, the Guria Development Union, within the framework of the project - "Popularization of Guria tourism potential using the resources of twin cities of European countries" - published Georgian and English-language agro-tourism maps of Guria, which indicate agro-tourism facilities. For example: opened in the village Tsikhisperdi Mzia Sharashidze's "Churchkhela enterprise", cooperative "Natanebi" opened in the village Natanebi, greenhouses and cold storage facility - strawberry production, in Lanchkuti in village the Nigo - the fish farm "Misho's area", in Lanchkhuti in the village Atsana - "Bichiko's Kvevris" (host Bichiko Chkhaidze), family hotel in Chokhatauri and fruit drying enterprise "Skiji House" (host Darejan Berdzenishvili) and others.

All this helps to attract visitors interested in agritourism in Guria, offering a variety of new agritourism products. To further develop and identify these opportunities, it is necessary to develop agriculture in the region.

Actively working in this direction Non-profit (non-com-

Diagram N 4. According to the data of 2019, during the tourist season, the number of visitors:
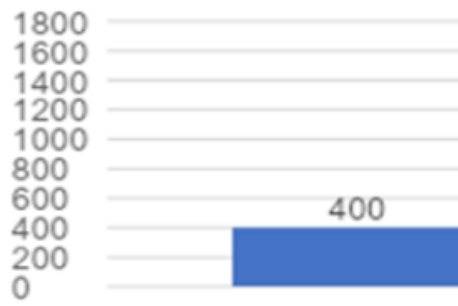

June

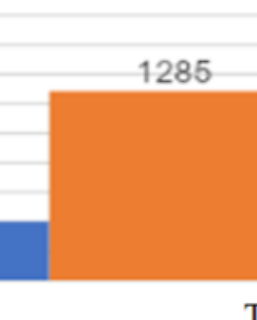

The number of visitors

August September $\quad$ October
1537

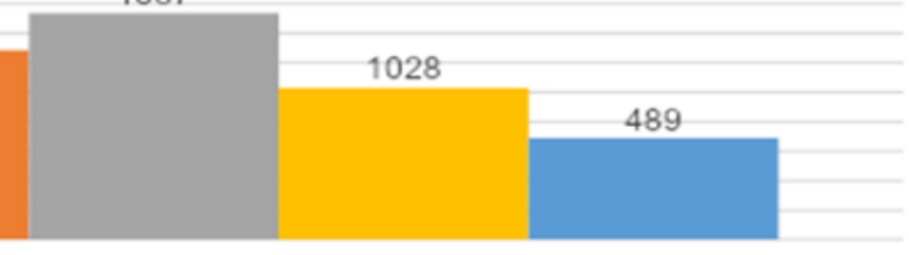

Source: Lanchkhuti Municipality City Hall, Tourism Service 2020. 
mercial) legal entity "Agricultural and Rural Development Agency", whose efforts in the 2014-2017 years in the region was carried out the following projects:

156 loans worth of amount of 19186228 GEL were issued within the framework of the preferential agro-credit project, co-financed by the Agency amounted to 4654495 eq. GEL.

5 new enterprises were opened ( 1 - preferential agro-credit, 1 - run in Georgia, 3 - in the framework of co-financing program of savings and processing enterprises) - amount invested - 9767 206 GEL (Guria, 2019: 57-58).

Due to the fact that the development of agro-tourism contributes to the growth of many related sectors, including agricultural production, trade, transport services, various tourism services, the development of agro-tourism is particularly important for the development of villages in the Guria region (Georgia, 2017: 26).

\section{SHORTCOMINGS IN THE DEVELOPMENT OF AGRO-TOURISM IN THE GURIA REGION AND WAYS TO OVERCOME IT}

As the results the research shows that, Guria region has significant resources for the development of agro-tourism, which need to be developed and used.

According to the Ministry of Environment Protection and Agriculture of Georgia, currently only 17 farms in Guria offer tourists overnight stays and agro-tourism services (Nikvashvili, 2020).

Farmhouse full potential to prevent a number of factors which have to overcome the demands of the tourism service market development, which will promote agro-tourism facilities in the capacity of employees (Galdava, et al, 2020).

An important role in this should be played by the intensification of state support measures for agro-tourism, which includes:

- Establishment of tax benefits;

- Ensuring the possibility of receiving a state grant;

- Provision of preferential credit resources;

- Development and implementation of projects and programs supporting agro-tourism development;

- Implementation of educational programs, professional training and qualification of persons involved in agro-tourism activities;

- Promoting the arrangement of tourist infrastructure in the municipalities of Guria region - regulation of access roads to the village, gas, electricity, internet, bathrooms.

In addition, we think that the following measures should be taken for the development of agro-tourism in the Guria region:

- Agro-tourism planning and management should be carried out at the level of separate municipalities, during the gradual implementation of which the local self-government should attract grants, investments, financial resources in this direction;
- Local production facilities for agricultural products should be established, which will contribute to the development of local production and employment of the local population;

- It is necessary to carry out marketing activities, which include studying customer behavior, focusing on its demand and organizing advertising on the Internet, with the help of travel agencies, with the involvement of local municipalities;

- $\quad$ significant advertising load will buy if the village Natanebi orange annual vintage tradition dispute inhabitants tourists participate, who will be able not only to the farmer families in the accommodation and catering possibility, but there should be close citrus juices and cans of industrial-Processing Factory, where tourists learn about the production process, purchase and taste the product;

- It is necessary to think of new agro-tourism routes and improve the existing one. For example, in this respect, one of the outstanding places is the village of Zedubani in Ozurgeti municipality, where the old settlement of Gurian feudal lords is located. The view from the village hill, which overlooks the entire Black Sea coast from Kobuleti to Poti and the Natanebi River Valley, is excellent for visitors. This place is a settlement of Nakashidzes. Nakashidze feudal lords were, the entire area belonged to a rural hillside visible, living in zedubani in these hills (the Nasakirali).

Nakashidze had arranged an artificial cave, which he allegedly used as a wine cellar or to store various products. There was a handmade tea factory. The entrance to the cave is on the north side of the hill and is invisible as it is covered by plants. The entrance is wide and the walls are made of bricks. The cave was used until the 1920s. According to a legend, the Chkhaveri wine stored in this cave was sent as a gift to Stalin during World War II. 7 ( Historical, 2019).

We think it is possible to renovate the mentioned place, set up a small farm and arrange it to receive agro-tourists. Or, in one of the municipalities of Guria, to arrange an old Gurian Oda, an ethnographic corner and an agro museum, Panchaturi, in the vicinity of the centre. There is a small farm, which will allow visitors to get acquainted with old and modern agricultural machinery and technology, history and ethnography of Guria, visit and get involved in the farm and finally taste the dishes and wine made by Gurian gastronomy in Panchaturi. Listen to Gurian folklore and have fun watching Khorum dance.

It is also possible to organize agro-tourism routes, during which it will be considered to involve tourists in farming activities, as well as to unload them with additional cognitive or entertaining activities. These can be: boating in the Imnati district of Kolkheti National Park, then fishing and picnicking, or visiting historical and landmarks, getting acquainted with the history and ethnography of the village, etc.

We suppose that in the future it is necessary to interest the locals in the Guria region and actively involve them in agritourism, as this will help improve their socio-economic conditions. 


\section{REFERENCES:}

Administration OF The President (16.06.2020), The President visited Guria region to support and promote local tourism, https://www.president.gov.ge/ge/News/Article/prezidenti-adgilobrivi-turizmis-mkhardacherisa-da;

Bedianashvili, G. (2018/2019) - Regional Social-Economic Systems and Territorial Structure of the Country in the Context of Modernization of Local Self-Government and Entrepreneurial Activity - Regional Review - Research Papers -14 -https:// search.proquest.com/openview/8046330b21fa0fc6fc14a4ac6e46eb3b/1?pq-origsite=gscholar\&cbl=2034462

Eradze, E. (2017) If science does not intervene in this matter, we will not be able to move forward, https://www.kvirispalitra. ge/mamul-deduli/33889-qam-saqmeshi-mecniereba-thu-ar-chaeria-tsin-ver-tsavalthq.html;

Galdava, M., Molashvili, N., Tsintsabadze, J., (28 September 2020). Agritourism in Georgia, https://iset-pi.ge/index.php/ka/ iset-economist-blog/entry/agroturizmi-sakartveloshi;

Gelovani, Kh. (2019), the whole of Guria in one yard, https://www.entrepreneur.com/article/337237;

Ghoghoberidze, T., Madzgharashvili, G., Peikrishvili., Napetvaridze, Ts., Baliashvili, L., Kordzakhia, Al., Kvezereli Sh., (2017). Beekeeping, Tbilisi;

Girkelidze, G. (2018,) Guria 2018 agro-festival held in Ureki, http://gurianews.com/article/mtavari/sazogadoeba/urekshi-agro-turistuli-pestivali-guria-2018-gaimarta;

Gugushvili, G., Gagua, Z., Khidasheli, N., (2013). Research Report: The Potential of Agritourism in the Guria region, Georgian Ecotourism Association's information, Tbilisi;

Gujabidze, F. (2020), "Lanchkhuti Municipality Tourism Service". Manuscript, Lanchkhuti;

Guria Region Development Strategy Implementation Monitoring Report, (2019), https://www.asocireba.ge/files/ SYS-GC-Guria-Regional-Strategy-Monitoring-2019n.PDF;

Hageman, M. (2019), 7 Wonders of Agritourism: Great farms to learn at and be entertained, https://www.agdaily.com/lifestyle/top-agritourism-destinations-united-states/;

Historical Monuments, (February 14, 2019 ), Nakashidze Settlement, https://guriatourism.ge/ka/archives/190;

Jabnide, R., Jabnide, N., (2016) Plsning of agro tourism in Georgia and its sustainable development, Sectoral and regional economy, Journal:140, https://nier.ge/images/statia_18_139-142.pdf;

Khartishvili, L., Salukvadze, G., Gugushvili, T., Pashalishvili, A., (2020). "Assessment and analysis of the potential of the Georgian agro-tourism market", https://info.parliament.ge/file/1/BillPackageContent/29136;

Kushashvili, S. (2019), "Household - when you want to share with Gurian ethnoculture", https://www.entrepreneur.com/ article/339244;

Nikvashvili, N. (2020), Georgia has perspectives for Agritourism development, https://www.forbeswoman.ge/post/isetpi-6;

Rural Development Strategy of Georgia 2017-2020, Tbilisi, 2017, http://enpard.ge/ge/wp-content/uploads/2015/05/\%E1\% 83\%A1\%E1\%83\%90\%E1\%83\%A5\%E1\%83\%90\%E1\%83\%A0\%E1\%83\%97\%E1\%83\%95\%E1\%83\%94\%E1\%83\%9A\%E1\%83 \%9D\%E1\%83\%A1-\%E1\%83\%A1\%E1\%83\%9D\%E1\%83\%A4\%E1\%83\%9A\%E1\%83\%98\%E1\%83\%A1-\%E1\%83\%92\%E1\%83 \%90\%E1\%83\%9C\%E1\%83\%95\%E1\%83\%98\%E1\%83\%97\%E1\%83\%90\%E1\%83\%A0\%E1\%83\%94\%E1\%83\%91\%E1\%83\%9 8\%E1\%83\%A1-\%E1\%83\%A1\%E1\%83\%A2\%E1\%83\%A0\%E1\%83\%90\%E1\%83\%A2\%E1\%83\%94\%E1\%83\%92\%E1\%83\%98 \%E1\%83\%90-2017-2020.pdf;

Shalamberidze, I. (2019). "Development of Agro-Tourism in Ozurgeti Municipality", Manuscript, Ozurgeti,

Sharashenidze, A. (2019). Development of Agro-Tourism in Chokhatauri Municipality, manuscript, Chokhatauri; THE Draft Law On "Agritourism" (2020). https://info.parliament.ge/file/1/BillReviewContent/264468;

Vadachkoria, M., Okrotsvaridze, A., Okrotsvaridze, L., (2011), Management of Tourism and Entertainment, Tbilisi;

Vashalomidze, A. (25.03.2011), Guria and Vineyard, http://www.gurianews.com/article/karmidamo-chemi/843;

Yasuo, Ohe., Ciani, A., (20 March 2012), Accessing Demand Characteristics of Agritourism in Italy, https://www.researchgate. net/publication/233675666_Evaluation_of_Agritourism_Activity_in_Italy_Facility_Based_or_Local_Culture_Based. 